
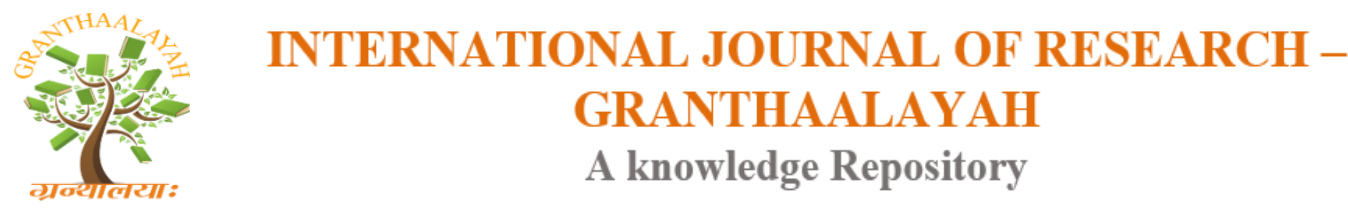

Management

\title{
EUROPEAN DIMENSIONS OF THE SOCIAL ENTERPRISES AND DEVELOPMENT OF THE SOCIAL ENTREPRENEURSHIP IN BULGARIA
}

\author{
Irina Atanasova ${ }^{* 1}$ \\ ${ }^{* 1} \mathrm{PhD}$, Assistant Professor, Faculty of Economics, Southwest University- 'Neofit Rilski', \\ Blagoevgrad, Bulgaria
}

\begin{abstract}
Social entrepreneurship has to be perceived in the context of social economy. It is the production, supply and / or organization of consumption of goods with a socially significant effect. The objectives of the paper are: to define the essence of the social entrepreneurship, its relation to the other business models and the social enterprise as an organizational subject of social entrepreneursh. The institutional framework and the legal foundations of these processes in the EU and Bulgaria have been outlined. Some specific problems - institutional, legal, economic are concerned and directions are given for solving them.
\end{abstract}

Keywords: Social Entrepreneurship; Social Enterprise; Legal Regulation of Social Entreprices; Development of the Social Entrepreneurship.

Cite This Article: Irina Atanasova. (2017). "EUROPEAN DIMENSIONS OF THE SOCIAL ENTERPRISES AND DEVELOPMENT OF THE SOCIAL ENTREPRENEURSHIP IN BULGARIA." International Journal of Research - Granthaalayah, 5(10), 175-183. https://doi.org/10.29121/granthaalayah.v5.i10.2017.2294.

\section{Introduction}

At the beginning of the new century, social entrepreneurship is a subject of increased scientific research. More and more public expectations are being addressed to it in order to solve socially significant problems, particularly in times of crisis. Social entrepreneurship should be seen in the context of the social economy. It is the production, supply and / or organization of consumption of goods with a socially significant effect. Social entrepreneurship is a voluntary nonprofit activity in the non-governmental, third sector, or it is an accompanying activity of the business in the form of corporate social responsibility. It is an economic process, related to the spending of significant resources (public, private, received in accordance with different programs of European funds), which is not necessarily profitable. 


\section{European Dimensions of the Social Enterprise}

Social entrepreneurship and social enterprises are key elements of the European social model. Their growing importance, especially during the crisis stimulates the creation of a political and institutional framework of these processes. The report of the CIRIEC (International Centre of Research and Information on the Public, Social and Cooperative Economy) ${ }^{1}$ indicates that the status of the social economy and the social enterprises are legally defined in a number of countries in the EU. More than two thirds of the EU states have adopted laws on the legal regulation of these processes. The different countries have various definitions for the social enterprises, which may vary and they exist in various forms -private companies, cooperatives, associations, voluntary organizations, charity organizations, etc.

The concept of the social enterprise is a popular term all over Europe, which describes a wide range of structures and organizations, developing business with the aim of achieving a social effect.

A social enterprise is an operator in the social economy whose main objective is to have a social impact rather than make a profit for their owners or shareholders. It operates by providing goods and services for the market in an entrepreneurial and innovative fashion and uses its profits primarily to achieve social objectives. It is managed in an open and responsible manner and, in particular, involves employees, consumers and stakeholders affected by its commercial activities. The term 'social enterprise' to cover the following types of business ${ }^{2}$ :

- Those for who the social or societal objective of the common good is the reason for the commercial activity, often in the form of a high level of social innovation.

- Those where profits are mainly reinvested with a view to achieving this social objective.

- Those where the method of organization or ownership system reflects the enterprise's mission, using democratic or participatory principles or focusing on social justice.

There is no single legal form for social enterprises. Many operate in the form of social cooperatives, some are registered as private companies limited by guarantee, some are mutual, and a lot of them are no-profit-distributing organizations like provident societies, associations, voluntary organizations, charities or foundations. The existing models of the social enterprise in the EU member states are based on the following basic approaches for the legal regulation of their activity:

- Countries, which have a separate legal framework of the social enterprise (a separate law) /Lithuania, Finland /;

- Countries, which do not have $\mathrm{s}$ special law and a requirement for a specific organizational form for a social enterprise, but they have a certain type of legal entity, performing social entrepreneurship activity. The legislation of the above mentioned countries provides number of promotional measures for their activity/ Italy-social

\footnotetext{
${ }^{1}$ The Social Economy in the European Union - 2012, Report prepared for the European Economic and Social Committee, http://www.ciriec.ulg.ac.be/en/publications/etudesrapports/the-social-economy-in-the-european-union-2012/

${ }^{2}$ COMMUNICATION FROM THE COMMISSION TO THE EUROPEAN PARLIAMENT, THE COUNCIL, THE EUROPEAN ECONOMIC AND SOCIAL COMMITTEEAND THE COMMITTEE OF THE REGIONS Social Business InitiativeCreating a favourable climate for social enterprises, key stakeholders in the social economy and innovation $/ *$ COM/2011/0682 final */ http://eur-lex.europa.eu/legal-content/EN/TXT/?uri=CELEX\%3A52011DC0682
} 
cooperatives, Portugal-social cooperatives for mutual assistance, Greece-social cooperatives with limited liability/;

- Countries in which for the purposes of the social enterprise, a new type of legal entity is created /England, France/;

- Countries in which there is no obstacle social entrepreneurship to develop under different legal forms, provided that these carry out business with social objectives /Germany,Sweden,Belgium/. For Example in Belgium, the Commercial Code has the legal figure of a commercial company with social objectives.

The countries in Central and Eastern Europe are missing/ with the exception of Lithuania and Poland/ special regulations of the social entrepreneurship.

The provision of social services, the integration of the long-term unemployed individuals and people in unequal position, the protection of the environment and the development of local communities are priority areas at European and national level.

For example in $\mathrm{UK}^{3}$ social enterprises are registered most frequently as commercial companies (limited liability companies), using status of charitable organization. There is a new legal form for the social enterprise, adopted in July 2005. The company should be in the interest of the Community". The Legal definition of social entrepreneur in UK is a "retailer engaged in a business with a social purpose.',

In Greece the definition for social enterprise is social entity with limited liability. The purpose of the social enterprises there is social, economic and vocational integration of mentally ill, socially weak individuals and vulnerable groups. The activities are related to production (agriculture and crafts), sale and performance of various services.

In Sweden there are two forms of the social enterprise. One is the etc. "entity for social activity" and the other one is "entity involved in the development of the Community". And the two forms have the status of Business Association (reunification of entities to meet the social needs through the development of their own self-enterprise). The aim of the social enterprises in Sweden is social inclusion and social integration of the members. The activities are aimed at the provision of goods and services for the free market and for the institutions. The social enterprises have state support which is expressed by the means of procedures, including public procurement, preferential contracts for social cooperatives. There is an opportunity for them to conclude contracts with public institutions. The benefits are that work is provided for individuals from vulnerable groups, the institution receives goods and services and the the social enterprise becomes more independent.

All European documents provide that the social entrepreneurship is an integral part of the civil society and the component of the sector of the social economy.

\footnotetext{
${ }^{3}$ Social Enterprise UK, https://www.socialenterprise.org.uk/Pages/FAQs/Category/FAQs
} 
Major strategic documents of the EU concerning social entrepreneurship are: strategy Europe $2020^{4}$; European employment strategy ${ }^{5}$; Social Business Initiative ${ }^{6}$; Regulation on the European Social Entrepreneurship funds ${ }^{7}$; etc.

The financial resources of the European Social Fund are directed to the following spheres of activity- support for employment and mobility, for better education; a chance for every individual; improvement of public services. This fund supports the creation of social entrepreneurship as an opportunity for new job positions to the long-term unemployed, for individuals with disabilities and individuals, living in underdeveloped municipalities. These objectives are concerning the implementation of the Priority 3 of the Strategy Europe 2020, which says, "achievement of inclusive growth by which to stimulate the economy with high levels of employment that would lead to territorial and social cohesion".

There is a published message from the European Commission "Initiative for social entrepreneurship - creating a favorable environment for the promotion of social enterprises" as they are the main actors in the economy and social innovativeness. The Social Business Initiative, launched in 2011, aims to: introduce a short-term action plan to support the development of social enterprises, key stakeholders in the social economy and social innovation and to prompt a debate on the avenues to be explored in the medium/long term. The plan contains 11 priority measures, organized around three themes:

- Making it easier for social enterprises to obtain funding

- Increasing the visibility of social entrepreneurship

- Making the legal environment friendlier for social enterprises

The first is to facilitate access to private funding; the mobilization of the European funds for the support of the social entrepreneurship. The Program for social change and social innovation in the implementation of the Regulation for the European funds for social entrepreneurship adopted by the EP and the Council of 17 April 2013 provides for the establishment of the European financial instrument in the framework of the 90 million euros. The second direction affects the improvement of awareness of the entrepreneurship. It promotes the Creation of a multilingual information and exchange platform for social entrepreneurs, business incubators and clusters, as well as social investors. Increase the visibility of EU programmes to support social entrepreneurs and make it easier to obtain funding.In this direction in Bulgaria there is a decision for the creation of a single register of the social enterprises and improving the legal environment.

The third theme aims to simplify the rules for awarding public aid to social and local services (which would benefit many social enterprises); make quality and working conditions more

\footnotetext{
${ }^{4}$ Europe 2020 strategy, https://ec.europa.eu/info/business-economy-euro-0/economic-and-fiscal-policy-coordination/eueconomic-governance-monitoring-prevention-correction/european-semester/framework/europe-2020-strategy_en

${ }_{6}^{5}$ European employment strategy, http://ec.europa.eu/social/main.jsp?catId=101\&langId=en\&furtherPubs=yes

${ }^{6}$ Social Business Initiative http://www.eesc.europa.eu/en/our-work/opinions-information-reports/opinions/social-businessinitiative

${ }^{7}$ European Social Entrepreneurship Funds, http://www.eesc.europa.eu/en/our-work/opinions-informationreports/opinions/european-social-entrepreneurship-funds
} 
important criteria for the awarding of public procurement contracts, particularly for social and health services The European Employment Strategy emphasizes that there is a need for a greater flexibility and security of the employment, the creation of more and better jobs. There are some actions, which will directly reflect on the organization and the behavior of the social enterprises. These are - education and training in the field of the social entrepreneurship, inclusion to the entrepreneurial activities of women, young people, unemployed, migrants; creating a favorable environment to promote the growth and the development of the enterprises; access to financing, expansion of electronic service and etc.

The need to create a more favorable and effective institutional environment for the functioning of the social enterprises and the provision of better financial opportunities are some of the challenges, which the EU is facing.

\section{Condition, Priorities and Problems Concerning the Development of the Social Entrepreneurship and the Social Enterprises in Bulgaria}

In Bulgaria social entrepreneurship solves one of the most difficult and serious social problems. It develops new social models of active social assistance, includes isolated economic and social groups in society. The social enterprises in Bulgaria are still unused business model. Currently the social enterprises are mainly non-governmental organizations registered in accordance with:

- the Bulgarian Law on the non-profit entities as non-government organizations with private or public benefits or foundations;

- the Commercial Law/the envisaged in it legal-organizational forms/;

- the Law on cooperatives;

- the Law for the crafts, when is a craft manufacturer;

Their activities are in different sectors with various subject of activity: delivery of social services, provision of employment of people with disabilities, mediation in finding work of unemployed individuals, provision of health services, activities in the field of education and other. In the realization of these activities, the main objective is not the production, but the achievement of a particular social effect for the individuals themselves.

Table1: Social enterprises in Bulgaria ${ }^{8}$

\begin{tabular}{|c|c|c|c|c|c|c|c|c|}
\hline $\begin{array}{c}\text { Legal } \\
\text { statute and } \\
\text { registration }\end{array}$ & $\begin{array}{c}\text { Participation } \\
\text { in the } \\
\text { economic } \\
\text { activity }\end{array}$ & $\begin{array}{c}\text { Social } \\
\text { aim for } \\
\text { public } \\
\text { interest }\end{array}$ & $\begin{array}{c}\begin{array}{c}\text { Distribution } \\
\text { of profits }\end{array} \\
\end{array}$ & $\begin{array}{c}\begin{array}{c}\text { Restrictions at } \\
\text { the } \\
\text { distribution of } \\
\text { profits }\end{array} \\
\end{array}$ & $\begin{array}{l}\text { Freezing of } \\
\text { assets }\end{array}$ & $\begin{array}{c}\text { Autonomy/ } \\
\text { organizational } \\
\text { independence }\end{array}$ & $\begin{array}{c}\text { Incorporated } \\
\text { management }\end{array}$ & $\begin{array}{l}\text { Average } \\
\text { number }\end{array}$ \\
\hline \multicolumn{9}{|l|}{ BULGARIA } \\
\hline $\begin{array}{l}\text { Non-profit } \\
\text { entities }\end{array}$ & some & yes & yes & $\begin{array}{l}\text { Yes-by } \\
\text { presumption }\end{array}$ & $\begin{array}{l}\text { Not } \\
\text { defined }\end{array}$ & Autonomous & $\begin{array}{l}\text { Encouraged } \\
\text { but not } \\
\text { required }\end{array}$ & $\begin{array}{l}36000 \\
(2013)\end{array}$ \\
\hline $\begin{array}{l}\text { Compnies, } \\
\text { owned by } \\
\text { non-profit } \\
\text { entities }\end{array}$ & yes & yes & yes & yes & $\begin{array}{l}\text { Not } \\
\text { defined }\end{array}$ & $\begin{array}{l}\text { Fully owned } \\
\text { subsidiary }\end{array}$ & $\begin{array}{l}\text { Encouraged } \\
\text { but not } \\
\text { required }\end{array}$ & $\begin{array}{l}85 \\
(2013)\end{array}$ \\
\hline $\begin{array}{l}\text { Labor } \\
\text { productivity } \\
\text { cooperatives }\end{array}$ & yes & yes & $\begin{array}{l}\text { Yes - except } \\
\text { for the } \\
\text { agricultural } \\
\text { cooperatives }\end{array}$ & $\begin{array}{l}\text { The levels are } \\
\text { defined in the } \\
\text { contract }\end{array}$ & $\begin{array}{l}\text { The levels } \\
\text { are defined } \\
\text { in a } \\
\text { cooperative }\end{array}$ & Not defined & Autonomous & $\begin{array}{l}251, \\
\text { includin } \\
\text { g } 30 \\
\text { speciali }\end{array}$ \\
\hline
\end{tabular}

\footnotetext{
${ }^{8}$ The data is provided by the Bulgarian national statistic institute, www.nsi.bg
} 


\begin{tabular}{|l|l|l|l|l|l|l|l|l|}
\hline & & & & & & & $\begin{array}{l}\text { agreement } \\
\text { coopera } \\
\text { tives for } \\
\text { people } \\
\text { with } \\
\text { disabilit } \\
\text { ies } \\
(2013)\end{array}$ \\
\hline $\begin{array}{l}\text { Specialized } \\
\text { anterprises } \\
\text { cooperatives } \\
\text { of people } \\
\text { with } \\
\text { disabilities }\end{array}$ & yes & yes & yes & $\begin{array}{l}\text { The levels are } \\
\text { defined in the } \\
\text { contract }\end{array}$ & $\begin{array}{l}\text { Not } \\
\text { defined }\end{array}$ & Autonomous & $\begin{array}{l}\text { Yes- } \\
\text { restricted to } \\
\text { members }\end{array}$ & $\begin{array}{l}125 \\
\end{array}$ \\
\hline
\end{tabular}

The legal status of the registered social enterprises in Bulgaria in 2015 is: associations-7\%, Limited liability companies-4\%, non-government enteties- $16 \%$, cooperatives- $15 \%$, non-profit entities $-8 \%$, foundations- $24 \%$, foundations with public useful activities-9\%.

In Bulgaria there are three basic model of a social enterprise.

- The most widely distributed model is that which creates employment and develops labor force. By economic activity are created jobs for people in unequal position, people with disabilities.

- They can be social establishments, which produce goods for a certain market. The aim is to carry out work therapy for people with disabilities /blind/, unemployed or in a state of social exclusion, so those individuals to have a decent standard of living.

- They can provide social services in exchange of payment for external customers and its members. The payment is due by a signed contract with the municipality or the state.

The main entities that are suppliers of social services are the municipalities and the state. The local authorities are primarily responsible for the organization and the delivery of these services. The most common form of municipal social enterprise is the Home social patronage. The municipalities refrain to delegate those activities to non-government organizations and in this way to exempt human resource and to offer another type of services

One of the main problems of the Bulgarian social entrepreneurship is the lack of qualified entrepreneurs who are willing to develop this type of initiatives. The social enterprises need additional capacity in the development of projects that would bring additional funding. It is necessary to develop organizing capacity, the strategic and the business planning in these structures.

Particular attention deserves the problem for the financing of the social enterprises and their tax regime. Depending on the legal form the social enterprises have different sources of financing. When is a company registrated in accordance with the Commercial law, it receives funds from fees for services, from operational programs to carry out the delegated activities, etc.

When is a non-government entity, registered in accordance with the Law on the non-profit entities, it the main sources are fees for services, funds from operational programs to carry out the delegated activities, funds from donors and donations. To sum up, the main sources in the 
year 2015 are: grants for Projects-30\%, donations and sponsorship-26\%, trade and economic activity-24\%, membership fee- $12 \%$ and others- $9 \%$.

Corporate Tax is due by the social enterprises for their profit when it is realized by business operations or for renting of property and the tax rate is $10 \%$.

Tax on social expenditure and tax on representative expenses also are due as well and they are $10 \%$. If the enterprise receives a dividend it also pays tax. Value Added Tax applies only to entities, which carry out activity within the meaning of Law on the Value Added Tax, but they must be registered at the National Revenue Agency.

Tax incentives are for donors- individuals, who donated amounts in favor of the social enterprises. They, according to the Law for Taxation of the income of the individuals, may be deducted $5 \%$ from the taxable income. The donation should be for health and healing establishments, specialized entities registered in accordance to the Law on the non-profit entities at the Central Registry, communes for treatment of drug addicts etc. Other tax incentives are provided in the Law for local taxes and fees, as these are tax incentives for enterprises which undertake to employ long-term unemployed persons, over 50 years or with reduced work ability.

A certain legal framework is necessary to ensure the incentives for the social enterprises, in particular to regulate the tax incentives, and to examine the various effects of such incentives.

The world practice knows some example for the promotion of the social economy -the so called "positive" discrimination. The Bulgarian legislation also has such examples. For example for the social enterprises, which as entities participate in the economic turnover are provided some hypotheses at the Law on Public Procurement ${ }^{9}$. According to it, the contracting authority is obliged to retain the participation in the procedure (the contest) for special entities or cooperatives or for individuals with disabilities when the subject matter of the contract is included in the list approved by the Council of Ministers and when the contract is carried out in accordance to a program for the protection of the employment of people with disabilities The European Commission recommends to facilitate the access of all social enterprises /not only of people with disabilities/ to public procurement as a "reserved contracts".

The vision and the main objectives for the promotion of the social economy in Bulgaria are laid down in the National Conception for the social economy ${ }^{10}$, adopted in the year 2011 and it follows the priorities of the Strategy Europe 2020. The Conception defines the criteria for the identification of enterprises and organizations by the social economy.

The accepted from the Council of Ministers National Strategy for the Youth 2010-202011 says that economic activity and the career development of young people must be improved by promoting the social entrepreneurship among them. However, a promotion of public-private partnership and social entrepreneurship in the field of services is needed. Bulgaria adopted National Strategy for the reduction of poverty and the promotion of social inclusion -2020 as

\footnotetext{
${ }^{9}$ Law on Public Procurement, http://www.aop.bg/fckedit2/user/File/en/Normativna\%20baza/zop_eng_new.pdf

${ }^{10}$ National Conception for the social economy http://seconomy.mlsp.government.bg/page.php?c=1\&d=54

${ }^{11}$ National Strategy for the Youth, http://mpes.government.bg/Documents/Documents/Strategii/strategy_youth_2012-2020.pdf
} 
well, whose objectives are to increase employment and income and the promotion of entrepreneurial activity

The long-term Strategy for the employment of people with disabilities 2011-2020 ${ }^{12}$ aims to provide the opportunity for the employment of those people, to improve their quality of life and much more their active social inclusion.

The Operational Program "Development of Human Resources", the area "Support of social economy"13 provides support to existing social enterprises, cooperatives of people with disabilities, specialized companies. Support is given as well to the creation of new forms of social enterprises, including protected workshops, contributing to improving of the social capital.

The self-employed individuals and social micro enterprises have the right to apply to the mechanism for microfinancing for employment and social inclusion. For the period 2014-2020 190 million euros will be ensured.

An Action Plan on social economy for 2014 -2015 is published ${ }^{14}$. The main priorities are: raising awareness of the interested parties on the essence and the functioning of the social economy; establishing partnerships and dissemination of good practices in the sphere of the social economy; development of an active supporting environment for the social economy and for the social enterprises; information insurance, creation of conditions for the education and training; evaluation of the economic and social impact on the employment, social inclusion and territorial cohesion.

One of the main problems remains the fragmented and the incomplete legal regulations for the social entrepreneurships and social enterprises. The adoption of a special law and a system of regulations are necessary to form the institutional framework of the social entrepreneurship. It is necessary to codify and promote best practices as well. Here is the place of the 'benchmarking', which will create national and international networks for the exchange of experience and knowledge.

The conclusion is that it is necessary and useful to coordinate the efforts of the state, nongovernment entities, civil entities, representatives of the private sector, and representatives from the academic community, of all that are relevant to the multiplication of social capital in society.

\section{Conclusion}

For more quality, effective and socially equitable production, supply and consumption of a number of socially significant public goods, currently and in the future, there will be a need for the social entrepreneurship and the social enterprises. Besides that, they are a specific business model and a form of social innovation; they are a compensation mechanism in terms of limited resources to resolve a number of social problems of the state. However, it is necessary to adopt a

\footnotetext{
${ }^{12}$ Strategy for the employment of people with disabilities https://www.mindbank.info/collection/country/bulgaria/disability_strategies_and_plans

${ }^{13}$ Ministry of labour and social policy, https://www.mlsp.government.bg/

${ }^{14}$ Action Plan on social economy for $2014-2015$ http://seconomy.mlsp.government.bg/page.php?c=2\&d=107
} 
special law on the social entrepreneurship and a number of regulations, as it is the practice in the other European countries. In this way will be created conditions for the institutions to perform effectively, the energy of the civil society, the state and the businesses will be mobilized, which will lead to the increase of the social capital in society .

\section{References}

[1] Action Plan on social economy for $2014-2015$ http://seconomy.mlsp.government.bg/page.php?c=2\&d=107

[2] COMMUNICATION FROM THE COMMISSION TO THE EUROPEAN PARLIAMENT, THE COUNCIL, THE EUROPEAN ECONOMIC AND SOCIAL COMMITTEEAND THE COMMITTEE OF THE REGIONS Social Business InitiativeCreating a favourable climate for social enterprises, key stakeholders in the social economy and innovation /* COM/2011/0682 final */ http://eur-lex.europa.eu/legal-content/EN/TXT/?uri=CELEX\%3A52011DC0682

[3] European Social Entrepreneurship Funds, http://www.eesc.europa.eu/en/our-work/opinionsinformation-reports/opinions/european-social-entrepreneurship-funds

[4] Europe 2020 strategy, https://ec.europa.eu/info/business-economy-euro-0/economic-and-fiscalpolicy-coordination/eu-economic-governance-monitoring-prevention-correction/europeansemester/framework/europe-2020-strategy_en

[5] European employment strategy, http://ec.europa.eu/social/main.jsp?catId=101\&langId=en\&furtherPubs=yes

[6] Law on Public Procurement, http://www.aop.bg/fckedit2/user/File/en/Normativna\%20baza/zop_eng_new.pdf

[7] Ministry of labour and social policy, https://www.mlsp.government.bg/

[8] National statistics institute, www.nsi.bg

[9] National Conception for the social economy http://seconomy.mlsp.government.bg/page.php?c=1\&d=54

[10] National Strategy for the Youth, http://mpes.government.bg/Documents/Documents/Strategii/strategy_youth_2012-2020.pdf

[11] Strategy for the employment of people with disabilities https://www.mindbank.info/collection/country/bulgaria/disability_strategies_and_plans

[12] Social Business Initiative http://www.eesc.europa.eu/en/our-work/opinions-informationreports/opinions/social-business-initiative

[13] Social Enterprise UK, https://www.socialenterprise.org.uk/Pages/FAQs/Category/FAQs

[14] The Social Economy in the European Union - 2012, Report prepared for the European Economic and Social Committee, http://www.ciriec.ulg.ac.be/en/publications/etudesrapports/the-socialeconomy-in-the-european-union-2012/

\footnotetext{
*Corresponding author.

E-mail address: atanasova_irina@yahoo.com
} 